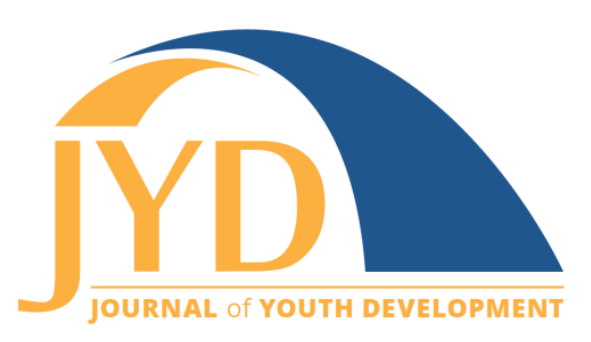

http://jyd.pitt.edu/ | Vol. 16 Issue 2-3 DOI 10.5195/jyd.2021.1027 | ISSN 2325-4017 (online)

\title{
Positive Youth Development: A Bridge to Connect Civic Education and Sustainable Development
}

\author{
Ashley Law \\ International Foundation for Electoral Systems \\ alaw@ifes.org \\ Virginia Atkinson \\ International Foundation for Electoral Systems \\ vatkinson@ifes.org
}

\begin{abstract}
Young people are not consistently or adequately valued by other global and community actors as contributing members and leaders. Given the current political context of democratic backsliding, school closures, and social distancing caused by the COVID-19 pandemic, young people are facing increased barriers to developing their democratic identities, learning how to be active citizens, and exercising their rights to participate in civic and political life. Now more than ever, development practitioners and the international community need to shift their approach to engaging young people in democracy and governance programs from one that views them as recipients to one that treats young people as partners and considers the unique environments in which they live. This paper argues that civic education programs that apply a positive youth development (PYD) approach can inform and shape how young people develop democratic identities and habits and directly link these identities and behaviors to building and sustaining democracies. The paper illuminates good practices and lessons learned through an exploration of global civic education programs demonstrating the utility of a PYD approach. The final section identifies areas to consider for the expansion and future of civic education programs to ensure their effectiveness and better link them to the Sustainable Development Goals.
\end{abstract}

Key words: civic education, youth participation, international development, Sustainable Development Goals

\section{Introduction}

Young people are a large population present in all communities, whose active participation, supported by societal actors, can lead to positive and sustainable contributions to democracy

(cc) EY New articles in this journal are licensed under a Creative Commons Attribution 4.0 License. This journal is published by the University Library System, University of Pittsburgh and is cosponsored by the University of Pittsburgh Press. The Journal of Youth Development is the official peer-reviewed publication of the National Association of Extension 4-H Youth Development Professionals and the National AfterSchool Association. 


\section{Civic Education and Sustainable Development}

building in their home countries and globally. Many traditional approaches to civic education focus on formal programs and fail to acknowledge community actors and processes (Crittenden \& Levine, 2018). One alternative is a Positive Youth Development (PYD) approach; according to the U.S. Agency for International Development (USAID), "PYD approaches build skills, assets and competencies; foster healthy relationships; strengthen the environment; and transform systems" (USAID, 2016, p. 10). PYD, as both a philosophy and approach, acknowledges that young people are affected by several factors that influence their development. Rather than ignore these factors, a PYD approach embraces and seeks to leverage "mutually beneficial relationships between youth and their family, peer groups, school, workplace, neighborhood, community, other government institutions, society, and culture to provide opportunities for youth to enhance their knowledge, interests, skills, and abilities" (USAID, 2016, p. 15). A PYD approach to formal and nonformal civic education addresses both individual and democratic identity development. It has been shown to increase not only young people's democratic knowledge and skills, but also engagement and participation in democratic processes (Sherrod, 2007). This paper therefore argues that using a PYD approach in civic education programs focused on democracy and governance (DG) will encourage the development of young people's democratic identities in a way that builds lifelong political participation habits, which can help achieve the Sustainable Development Goals ([SDGs]; UN, 2020).

A healthy democracy is one that supports the inclusion of all people, whether or not they have reached the age of enfranchisement and can formally participate in elections. Currently, the global youth population includes 1.8 billion people aged 10 to 24 years old (United Nations [UN], 2018, p. 4) with nearly two-thirds between the ages 15 and 24 (United Nations Department of Economic and Social Affairs [UNDESA], 2020, p. 5). Of this population, the UN estimates that $90 \%$ reside in developing countries (UN, 2018, p. 4). For countries that define young people up to 30 years old, the global population expands to $50 \%$ (U.S. Agency for International Development [USAID], 2012, p. 3). The COVID-19 pandemic has negatively affected youth globally, with school closures impacting about $90 \%$ of enrolled learners (UN, n.d.-a), and posed barriers to their participation in civic and political life. International development practitioners should adjust their approach to engaging young people in DG programs through civic education initiatives to mitigate detrimental effects from COVID-19 on young people and democracy writ large.

Scholars have noted that the method of delivery and environment for learning are just as important as the content in civic education programs; further, research explains that "basic 


\section{Civic Education and Sustainable Development}

education plays a key role in shaping basic forms of civic participation" and can be linked to an increase in the likelihood of a person's decision to vote and be an active citizen (Larreguy \& Marshall, 2017, p. 38). The World Bank, for example, suggests civic engagement as a key avenue for supporting young people to become part of an active citizenry, thereby linking individual development to community development (Bussolo et al., 2006). This connection underpins self-identity constructs and is well incorporated into the PYD approach and civic education programs, which seek to develop democratic attitudes, norms, and behaviors. By employing a PYD approach to civic education program design, practitioners can better connect young people's personal development with their democratic identities and facilitate a more democratically minded citizenship that possesses the necessary tools and relationships to actively contribute to society. Drawing on diverse case studies, this paper seeks to inform civic education program design, noting good practices and lessons learned, as a means to demonstrate how civic education programs that apply a PYD approach can lead to more inclusive and sustainable democracies.

\section{The Link Between Civic Education and Sustainable Development}

Globally, young people report that they view political leaders and institutions as unresponsive to their interests and demands, which has led to an uptick in political apathy and disillusionment as well as increased mistrust that elected leaders will prioritize their concerns and policy views (Consortium for Elections and Political Process Strengthening, 2019, p. 8). This has likely been a contributing factor to the poor representation of young people in their national governments; only $2.6 \%$ of the world's parliamentarians are under 30 (Inter-Parliamentary Union, 2021, p. 7). Considering the large global youth population and their potential impact, the UN and other international entities recognize the "unique demographic dividend that can contribute to lasting peace and prosperity" (UN Security Council, 2015) that accrues when societies provide spaces for young people to be involved in decision-making processes. Furthering this effort, the UN Secretary General appointed an Envoy on Youth who works directly with young people to advocate and advance progress on the SDGs (UN, n.d.-b).

Importantly, SDG 4 specifically calls for "inclusive and equitable quality education" and "lifelong learning opportunities for all" (UN, 2020, p. 32). In essence, effective civic education teaches young people how to constructively engage and participate in civic and political life, providing participants with an overview of "all the processes that affect people's beliefs, commitments, capabilities, and actions as members or prospective members of communities" (Crittenden \& 


\section{Civic Education and Sustainable Development}

Levine, 2018, p. 1). Therefore, civic education programming can provide a roadmap for young people of all ages to develop internal beliefs and values that, in turn, can be translated into democratic habits that effect change locally, nationally, and globally. However, challenges to civic education efforts-such as young people's informal participation methods and lack of trust in government systems and processes-pose barriers to their formal participation (Atkinson et al., 2020). Under SDG 4, PYD-designed civic education activities can directly address these challenges and connect the development of young people's democratic identity to their contributions to democracy efforts globally (UN, 2020). More effective civic education programming will also help equip young people to actively engage in promoting peace, justice, and strong institutions (SDG 16).

\section{Good Practices and Lessons Learned in Civic Education}

There are promising practices in the field of civic education that already incorporate elements of PYD into program design and implementation, yet more can be done to support young people to develop democratic identities and connect them with actors involved in democratic processes. As with all impactful programs, the design stage must begin with a thorough analysis and evaluation of the context (Kaufman, 2011) for programming, culminating in a comprehensive mapping of the complicated and interconnected dynamics among young people, democratic actors, processes, and systems in a community. The good practices identified in this section build upon this assumption and highlight four challenges that are common to traditional approaches to civic education, but can be avoided by applying a PYD approach:

- failure to design accessible and inclusive civic education programs,

- lack of relationship-building opportunities for young people to interact with formal actors and institutions,

- insufficient training for educators delivering civic education curricula, and

- inability to adapt civic education programs to young people's specific environment.

\section{Failure to Design Accessible and Inclusive Civic Education Programs}

Young people have unique experiences based on their gender, race, ethnicity, religion, disability, sexual orientation, and other factors. Societal norms and assumptions associated with these identities will impact a young person's engagement in civic life. Recognizing this fact, the International Foundation for Electoral Systems ([IFES]; n.d.) conducted an intersectionality assessment in the Dominican Republic in 2018 that found that young people with disabilities 


\section{Civic Education and Sustainable Development}

experience legal, physical, attitudinal, and informational barriers to political participation, including voting, serving as poll workers or observers, joining a political party or running for office (IFES, 2018). Youth without disabilities identified nepotism and clientelism as the main reasons they do not participate more actively in political life, whereas youth with disabilities identified accessibility issues and stigma as the main barriers to their political engagement. Young men and women with disabilities were less likely to identify themselves as leaders in their communities compared to adults with disabilities and young people without disabilities.

IFES used the findings of the assessment to develop a tailored political leadership course for young Dominicans with disabilities, which was implemented in partnership with a Dominican disabled persons' organization and university. Each class had sign language interpreters, and course materials were provided in formats accessible to people who use screen readers. The course built young people's soft skills, such as public speaking and advocacy, and provided students with civic education on topics such as the fundamentals of democratic participation and the political structure of the country. Classroom learning was supplemented with hands-on activities, including visits to political and government institutions and guest lectures by local experts. Young people with disabilities also had the opportunity to practice the skills they developed through the course and build their professional experience with internships, such as at the election management body and at municipal legislatures. Three out of 15 young people were hired as permanent staff at their host institutions. This PYD approach shows the importance of developing accessible and inclusive civic education programs that mix formal and nonformal learning and engage political and nonpolitical actors who can shape participant experiences and opportunities for future participation.

International development practitioners should develop tailored and accessible approaches to civic education programs that address the unique barriers and experiences of a diversity of young people to meet all facets of a PYD approach; further, practitioners should design inclusive programs to avoid additional marginalization of populations such as young people from ethnic or religious minorities; lesbian, gay, bisexual, transgender and queer (LGBTQ) youth; and young people who are displaced. For example, young people with disabilities cannot participate in online learning when platforms are not compatible with assistive devices, like screen readers. As with any program, practitioners should ask students what reasonable accommodations they need to participate in the course and provide materials in relevant languages for Indigenous and ethnic minority youth, as appropriate. Practitioners should also ensure civic education content covers the international legal framework protecting the rights of all people, such as the 


\section{Civic Education and Sustainable Development}

UN Convention on the Rights of the Child, UN Convention on the Rights of Persons with Disabilities, UN Convention on the Elimination of All Forms of Discrimination against Women, and the International Labor Organization Convention 169 on Indigenous and Tribal Peoples. Finally, practitioners must create meaningful relationships between young people and civil society members and political leaders who can provide further learning opportunities, in knowledge and action, and familiarize young people with formal institutions.

\section{Lack of Relationship-Building Opportunities for Young People to Interact With Formal Actors and Institutions}

One of the biggest challenges to young people's political participation is a lack of access to formal decision-making processes and unsupportive actors and systems that do not enable this access. These challenges have been exacerbated by the pandemic (Law, 2020). Policymakers and elected leaders typically do not value young people's opinions nor see them as equals in this space. Therefore, they do not create opportunities for young people to formally participate during legislative processes nor open the doors to where legislative decisions are made. While young people take on a consultative role in some countries and UN processes, many national and regional strategies and policies do not reflect young people's concerns and priorities. Exclusionary processes and systems are reported as one of the main drivers behind young people's apathy toward politics and lack of trust in government systems, which has led to a lower voter turnout among youth (UNDESA, 2016). Civic education rooted in a PYD approach offers a platform to address these challenges, particularly if it includes ongoing opportunities for young people to learn about their democratic systems through the lens of various democratic actors.

A prime example of this approach has been ongoing in New Zealand since 1994. Each parliamentary term, the Ministry of Youth Development and the Office of the Clerk organize a 2day Youth Parliament in the House of Commons to introduce young people aged 16 to 18 to the parliamentary process and the responsibilities of a Member of Parliament (MP). The Youth Parliament connects young people to their leaders, provides insights into the daily tasks of a $\mathrm{MP}$, and connects young people to the media with a Youth Press Gallery. Each iteration, 120 young people are selected as Youth MPs to participate in the program, which includes a 2-day Parliamentary event. Youth MPs also carry out community projects alongside their national MPs, such as facilitating youth forums, setting up youth councils or working with schools to increase civic education (Ministry of Youth Development [MYD], 2019). Twenty young people are selected to take part in the Youth Press Gallery, which teaches young members to write press 


\section{Civic Education and Sustainable Development}

releases and tools and techniques to keep the public informed about the actions Youth MPs are undertaking (MYD, 2019). One Youth MP from the 2019 cohort reflected on their time and said, "[It] was an overall good experience, it gave an insight of what MPs do when they are sitting in the house, and also having relationships with MPs, Youth MPs, and other parliamentary staff" (MYD, 2019, p. 2). Former MP, and one of the youngest MPs at the time, Darren Hughes was the first ever Youth MP to be elected to New Zealand's Parliament, demonstrating the career path an opportunity like this can afford young people interested in politics (Trevett, 2011).

New Zealand's Youth Parliament incorporates all elements of the PYD approach and provides opportunities for partnership building between political actors who directly mentor Youth MPs during the role-play experience. The Youth Parliament framework also increases young people's knowledge and skills about their country's government structure and processes, connects them with like-minded individuals, promotes networking with their communities and development processes, and sheds light on the real potential for a career in government. The replication of this model at various government levels, including community levels, and across organizations, schools, or other community centers could facilitate a wider exposure to and understanding of youth participation in decision-making processes at multiple levels. Programs should be developed from a lens of multiple and diverse perspectives to provide ample chances for young people to learn about the dynamic democratic structure and the many ways they can contribute and participate within it.

\section{Insufficient Training for Educators Delivering Civic Education Curricula}

Theorists postulate that children and young people are shaped by their experiences and environment and that influential actors can negatively or positively affect their development, including how they formulate their identities, values, and beliefs (Hart et al., 1997). Young people internalize their experiences, especially at younger ages, and that can influence their level of confidence and future engagement opportunities throughout their lives. Teachers can play a strong role in facilitating knowledge and relationship-building between young people and other community actors. Yet, targeted activities to illuminate good practices for doing so and encouraging this interaction remain limited.

During the 2018-19 academic year, IFES piloted a university-level civic education course, Democracy: From Theory to Practice, with multidisciplinary students across eight Ukrainian universities; the program has since been expanded to over 30 universities in 16 cities in Ukraine. Based on IFES' global university-level civic education methodology, Strengthening 


\section{Civic Education and Sustainable Development}

Engagement Through Education for Democracy (SEED), the course was tailored to the Ukrainian context and seeks to foster democratic values and attitudes through interactive and participatory teaching and curricula. The knowledge-based components cover topics such as democratic governance, human rights, civil society, and citizen engagement while drawing on cross-cutting themes such as digital literacy, gender equality, accessibility, and social inclusion. The SEED methodology utilizes a student-centered teaching approach that encourages students to gain practical skills such as critical thinking, teamwork, problem-solving, public speaking, and consensus building, and culminates in a capstone project in which students design an action project for implementation in their communities related to course topics (IFES, 2018). Notably, 11 Ukrainian students from across Ukraine who participated in the course created Youth Democratic Association (YODA), a registered nongovernmental organization (IFES, 2020); YODA launched "Go Vote," a nationwide voter education campaign targeting young and first-time voters ahead of the 2020 local elections (IFES Ukraine, 2020). In response to the pandemic, the course has since been adapted for implementation online and includes accessibility features, such as contrast mode and sign language interpretation, that have all been pilot-tested with students with disabilities (IFES Ukraine, 2021).

While SEED enhances young people's knowledge and skills around active citizenry, it also promotes key relationship-building opportunities for young people and their communities through the action project component. The action projects facilitate a sense of belonging and purpose that is crucial to democratic stability. This is evident from student feedback provided in course evaluations. Prior to the course, many students reported not perceiving any role for themselves in society or a drive for change (Burroughs, 2019). After completing the civic education program, " $88 \%$ felt the course helped them better understand methods for citizen engagement" (Burroughs, 2019, p. 22). Many students cited ways they had already taken action, including organizing petitions, working on anti-bullying programs with school authorities, and partnering with local governments on social service issues like access to public transportation (Burroughs, 2019).

Course instructors observed that students actively transformed their attitudes and behaviors every week, displaying a shift toward more tolerance and acceptance of diverse opinions as the course progressed. The encouraging results of the SEED methodology linked to increased agency and shifts toward democratic attitudes and values were visible not only in students, but importantly, in teachers as well (Burroughs, 2019). During the initial stages of implementation, program designers found that some teachers held traditional views of democracy, and pieces of 


\section{Civic Education and Sustainable Development}

the curriculum clashed with their understanding of the topic. As a result, a training for teachers on democratic international standards was required, which shifted educators' notions and behaviors as they taught the course. Traditionally, civic education programs have often mirrored the country's definition of democracy rather than adhering to international standards. At times, this has resulted in teachers largely teaching a formal civic education curriculum derived from hierarchical and nationalistic perspectives that fail to instill and promote democratic values and attitudes. Practitioners should consider including thorough briefings or workshops with those who are facilitating civic education initiatives to ensure inherent biases or incorrect assumptions of democracy do not impact the program goals.

\section{Inability to Adapt Civic Education Programs to Young People's Specific Environment}

Given the continued rise in young people's engagement with social media due to the COVID-19 pandemic (Suciu, 2020), young people have adapted how they participate in civic and political life and are turning to digital activism as a primary means for engagement. According to a recent report, the largest group of Facebook users are between 25 and 34 years old (Kemp, 2021). Evidence also suggests that younger users between 13 and 18 years old are now gathering their news from social media (Kahne \& Bowyer, 2019). The current "infodemic," (Reppell et al., 2020, p. 3) or flood of information streaming across young people's news feeds, is at a higher volume than ever. There is a timely need for practitioners to focus on strengthening young people's media literacy by building skills that equip them with "the ability to access, analyze, evaluate, create and act using all forms of communication" (Kahne \& Bowyer, 2019, pp. 212-213). Adding media literacy to civic education programs will also facilitate a more communal and ethical approach to facilitating an online community where young people can learn how to better influence and connect with decision-makers.

Faktabaari, a Finnish fact-checking organization, created the Fact-Checking for Education and Future Voters toolkit for Finnish schools to teach students about media literacy, including media bias and how fact-checking can reduce the spread of misinformation and disinformation (FactBar EDU, 2018). In one classroom activity, teachers link fact-checking to elections through an exercise that teaches students about the political system and roles within it, builds analytical and fact-checking skills, and creates a sense of ownership and place in Finland's democracy. Through various role-play scenarios, students are empowered to act as real-time fact checkers in political debates and mock elections, thereby bridging digital and political participation. 
Similar to the SEED methodology, the classroom-based toolkit uses a student-centric perspective leveraging students' assets and agency in role-playing exercises for them to experience leadership roles as political actors and journalists. Moreover, the toolkit encourages relationship-building with political actors, suggesting that teachers invite political candidates and journalists to interact with students to facilitate a better understanding of these roles, duties, and responsibilities in the democratic process. The fact-checking voter literacy toolkit also draws upon the current environment in which young people are engaging by linking participation to media literacy and using this to expand their knowledge, skills, and participation into more formal electoral processes.

Research shows that media literacy initiatives can positively impact young people's sense of agency around politics and might actually increase more equitable political engagement among young people. However, there is an important caveat that this study illuminates: While it is useful and productive to integrate media literacy learning into civic education programs, "Youth who get involved in online political activities tend to be those who are politically interested and active, who possess digital skills, and who are college educated" (Kahne \& Bowyer, 2019, p. 220). With this evidence in mind, practitioners should consider ways to expand media literacy programs into nonformal settings such as learning centers or through home-based toolkits to better reach more diverse groups of young people who are not in school.

\section{Recommendations for Future Civic Education Programs}

The aforementioned examples of effective civic education activities should be improved and expanded to bolster a growing global youth cohort of democratically minded and active citizens to contribute to achieving the SDGs. Civic education that follows the PYD approach is more important than ever. Learners, including those with disabilities and those from other marginalized groups, may be experiencing some of the most adverse effects from the COVID-19 pandemic because of time lost during school closures; a loss of assistive services in formal school settings; and because disability, gender, ethnicity, and other factors might impact a young person's access to the Internet (UNESCO Bangkok, 2020). These barriers will significantly impact young people's engagement in both formal and nonformal civic education and require an expansion of the actors involved in civic education programs and the incorporation of current topics important to young people. Overall, key recommendations for applying a PYD approach to civic education to bridge individual and community development include the following:

- using participatory approaches to connect diverse actors, 


\section{Civic Education and Sustainable Development}

- training educators in international standards,

- incorporating digital learning, and

- contextualizing content to lived realities of diverse youth populations.

\section{Use Participatory Approaches to Connect Diverse Actors}

Civic education initiatives offer a safe space for young people to explore, learn, and engage with topics related to civic and political life. Yet, more can be done to facilitate direct interaction with community and government actors and processes. Experiential and hands-on learning, such as role-play and simulation exercises, and relationship-building through field trips or class visits with political actors can instill a better understanding of the individual impact of young people's participation in their communities and globally. International practitioners designing civic education programs can also use this opportunity to tackle traditional norms, such as that young people are not old or wise enough to engage, by incorporating more community stakeholders into civic education activities. This approach aligns well with PYD as it brings together young people with their communities, including political and community leaders, to address socio-cultural barriers that exclude young people's participation. These "influential personalities" (Pirio, 2019, p. 15) can model positive and supportive behavior and promote young people's participation, thereby shifting youth participation narratives into positive ones that promote their contributions to their communities.

\section{Train Educators in International Standards}

Both formal educators, such as teachers, and nonformal educators, such as family members and community leaders, play pivotal roles in young people's lives, especially in how they present curricula content and influence, purposefully or not, how learners interpret it. As such, it is imperative that international practitioners consider the context within which they are implementing civic education programs and the inherent biases that educators may hold that contradict curriculum learnings. Conducting trainings with educators to review civic education content and discuss concepts that might hold different meanings will prove beneficial to ensuring civic education is delivered in the manner intended and potentially result in secondary program benefits, aligning democratic knowledge with international standards among educators globally. Moreover, civic education initiatives should be developed with an understanding that actors such as family members, caregivers, and peers may become teachers or facilitators during certain situations, like a pandemic, when access to schools or avenues for young people's participation are blocked or drastically changed. 


\section{Civic Education and Sustainable Development}

\section{Incorporate Digital Learning}

Young people with Internet access have already adjusted their means of participation during the COVID-19 pandemic to continue engaging with the world in a more digital way; practitioners should follow their lead and adapt civic education programing to reflect this trend to enhance continued participation. Practitioners could consider civic education programs that digitize or gamify learning, including simulations that allow young people to step into political actors' roles to achieve a goal, for example, as a virtual voter, candidate, or election official to better understand electoral processes and their roles within them. Games and interactive online activities can also be developed to walk through the process of elected leaders signing a bill or the legislative process of how a law is drafted similar to the Youth Parliament. Additionally, research shows that "older age groups are the fastest-growing segments amongst some of the top platforms' audiences" (Kemp, 2021). This trend offers a new opportunity for young people to bridge generational divides and facilitate intergenerational engagement on critical issues across demographics and levels of government. Moreover, adaptation of programs into digital formats will also help to combat the democratic learning gap that learners out of school are experiencing and help to mitigate the stall in advancing progress toward SDG 4, quality education. Yet, this will be effective for diverse learners only if practitioners consider accessibility issues to avoid exacerbating the digital divide for young people with disabilities and young people with low or no Internet access.

\section{Contextualize Content to Lived Realities of Diverse Youth Populations}

The COVID-19 pandemic has emphasized the need to design civic education programs in an iterative way that allows them to be adjusted for new contexts and easily adapted to changing environments. Civic education should prioritize and reflect elements important to young people such as patterns in their participation habits, areas of interest like climate change, and sociocultural factors. While concepts of equality and equity underpin civic education programs, these same programs sometimes fail to engage some of the most marginalized youth including young women, youth with disabilities, young people from ethnic or religious minorities, LGBTQ youth, young people who are displaced, and Indigenous youth as well as young people who are not engaged in formal education, employment, or training programs. Patterns of engagement and topics of interest will overlap among different youth populations and also vary in terms of priorities. Practitioners should proactively reach out to diverse groups of young people and provide knowledge building and opportunities to enhance relevant and important skills, and 
specific to the barriers they experience such as learning about international standards that protect the rights of marginalized groups.

\section{Looking Forward to COVID-19 Recovery Strategies}

International development practitioners should consider this important and overarching question: At what age should civic education programs begin? The formative years of one's development is an ideal time for children and young people to explore their democratic ideals and habits as this is the stage in life when they are creating their beliefs and values and shaping their identities (Hart et al., 1997). As both a responsive and proactive measure, civic education practitioners should embrace this notion during the COVID-19 pandemic and consider how best to integrate learning across all age groups. Should preschool-aged children, for example, be exposed to democratic learning earlier in life? Then, as they grow, habits related to learned knowledge and skills could possibly become more engrained and thus be sustained during pandemics-leading to a more resilient democratic citizenry.

The COVID-19 pandemic and related effects on young people have created an opportunity for an overdue shift in how we design civic education programming. When PYD approaches are employed, young people are better equipped to help engage both domestically and internationally on DG-related challenges exasperated by the pandemic. Engaging young people in conversations and processes focused on post-COVID-19 recovery strategies will be integral to community resilience in overcoming this pandemic. Civic education is uniquely placed to be the link that international practitioners are looking for to both overcome current challenges to sustainable development and advance global SDGs.

\section{References}

Atkinson, V., Applegate, M., \& Aaberg, R. (2020). IFES COVID-19 briefing series: Inclusion and meaningful participation. International Foundation for Electoral Systems. https://www.ifes.org/publications/ifes-covid-19-briefing-series-inclusion-and-meaningful-politicalparticipation

Burroughs, G. (2019). Democracy: From theory to practice evaluation report. International Foundation for Electoral Systems. https://ifesukraine.org/wp-content/uploads/2019/11/IFES-Ukraine-Democracyfrom-Theory-to-Practice-Pilot-Eval-v1-2019-05-23-Eng.pdf 
Journal of Youth Development | http://jyd.pitt.edu/ | Vol. 16 Issue 2-3 DOI 10.5195/jyd.2021.1027

Civic Education and Sustainable Development

Bussolo, M., Fox, L., Raju, D., Bundy, D. A. P., Viner, R. M., Brudevold-Newman, A., \& Gill, I. S. (2006, September). World development report 2007: Development and the next generation. World Bank Group. https://doi.org/10.1596/978-0-8213-6541-0

Consortium for Elections and Political Process Strengthening. (2019). Raising their voices: How effective are pro-youth laws and policies? $\underline{\text { https://www.ifes.org/publications/raising-their-voices }}$

Crittenden, J., \& Levine, P. (2018, August 31). Civic education. In E. N. Zalta (Ed.) The Stanford encyclopedia of philosophy (Fall 2018 ed.). https://plato.stanford.edu/entries/civic-education/

FactBar EDU. (2018). Fact-checking for educators and future voters. https://faktabaari.fi/assets/FactBar EDU Factchecking for educators and future voters 13112018.pdf

Hart, R., Daiute, C., Iltus, S., Kritt, D., Rome, M., \& Sabo, K. (1997). Developmental theory and children's participation in community organizations. Social Justice, $24(3$ (69)), 33-63. http://www.jstor.org/stable/29767020

International Foundation for Electoral Systems. (n.d.) Who we are. https://www.ifes.org/who-we-are International Foundation for Electoral Systems. (2018, March 9). New intersectionality assessment framework. https://www.ifes.org/news/new-intersectionality-assessment-framework

International Foundation for Electoral Systems. (2018, October 16). "Democracy: From theory to practice" university course starts in Ukraine. https://www.ifes.org/news/democracy-theorypractice-university-course-starts-ukraine

International Foundation for Electoral Systems. (2020, February 6). Civic education course alumni unite to engage more citizens in democracy. https://www.ifes.org/news/civic-education-course-alumniunite-engage-more-citizens-democracy

International Foundation for Electoral Systems Ukraine. (2020, October 27). Go vote on local elections 2020: NGO "Youth Democratic Association" (YODA) [Video]. YouTube.

https://www.youtube.com/watch?v=KWR41cwIrh0

International Foundation for Electoral Systems Ukraine. (2021, February 25). Innovative university civic education course expands to the digital space. https://ifesukraine.org/news/innovative-universitycivic-education-course-expands-to-the-digital-space/?lang=en

Inter-Parliamentary Union. (2021). Youth participation in national parliaments: 2018. https:// www.ipu.org/resources/publications/reports/2018-12/youth-participation-in-national-parliaments $\underline{-2018}$

Kahne, J., \& Bowyer, B. (2019). Can media literacy education increase digital engagement in politics? Taylor and Francis. https://doi.org/10.1080/17439884.2019.1601108

Kaufman, L. (2011). Community youth mapping, a tool for youth participation and program design. USAID. https://pdf.usaid.gov/pdf docs/pnadz225.pdf 
Journal of Youth Development | http://jyd.pitt.edu/ | Vol. 16 Issue 2-3 DOI 10.5195/jyd.2021.1027

Civic Education and Sustainable Development

Kemp, S. (2021, January 21). Digital 2021: The latest insights into the 'state of digital'. We are social. https://wearesocial.com/blog/2021/01/digital-2021-the-latest-insights-into-the-state-of-digital

Larreguy, H., \& Marshall, J. (2017). The effect of education on civic and political engagement in nonconsolidated democracies: Evidence from Nigeria. The Review of Economics and Statistics, 99(3), 387-401. https://doi.org/10.1162/rest a 00633

Law, A. (2020, May 22). How to boost youth political participation during COVID-19. International Foundation for Electoral Systems. https://www.ifes.org/news/how-boost-youth-politicalparticipation-during-covid-19

Ministry of Youth Development, Government of New Zealand. Youth parliament 2019. (2019). http://www.myd.govt.nz/documents/youth-parliament-2019/final-youth-parliament-2019-a3.pdf.

Pirio, G. (2019). Improving development outcomes through social and behavior change communication, applying a government lens. U.S. Agency for International Development. https://pdf.usaid.gov/pdf docs/PA00TG2X.pdf

Reppell, L., Martin-Rozumilowicz, B., \& Mohan, V. (2020). IFES COVID-19 briefing series: Preserving electoral integrity during an infodemic. International Foundation for Electoral Systems. https://www.ifes.org/publications/ifes-covid-19-briefing-series-preserving-electoral-integrityduring-infodemic

Sherrod, L. (2007). Civic engagement as an expression of positive youth development. In R. K. Silbereisen \& R. M. Lerner (Eds.), Approaches to positive youth development (pp. 59-74). Sage. https://in.sagepub.com/sites/default/files/upm-assets/15175 book item 15175.pdf

Suciu, P. (2020, May 20). Screen time and social media use among teens continues to rise. Forbes. https://www.forbes.com/sites/petersuciu/2020/05/21/screen-time-and-social-media-use-amongteens-continues-to-rise/

Trevett, C. (2011, March 23). Hughes sought career in politics from early age. NZ Herald. https://www.nzherald.co.nz/nz/hughes-sought-career-in-politics-from-earlyage/3W4WUVXUDSBVWHBJI2FU677UDE/

UNESCO. (2020, June 6). United Nations secretary-general warns of education catastrophe, pointing to UNESCO estimate of 24 million learners at risk of dropping out. https://en.unesco.org/news/secretary-general-warns-education-catastrophe-pointing-unescoestimate-24-million-learners-0

UNESCO Bangkok. (2020, May 4). Empowering students with disabilities during the COVID-19 crisis. https://bangkok.unesco.org/content/empowering-students-disabilities-during-covid-19-crisis

United Nations. (2018). United Nations youth strategy. https://www.un.org/youthenvoy/wpcontent/uploads/2018/09/18-00080 UN-Youth-Strategy Web.pdf 
Journal of Youth Development | http://jyd.pitt.edu/ | Vol. 16 Issue 2-3 DOI 10.5195/jyd.2021.1027

Civic Education and Sustainable Development

United Nations. (2020). The sustainable development goals report 2020.

https://unstats.un.org/sdgs/report/2020/The-Sustainable-Development-Goals-Report-2020.pdf

United Nations. (n.d.-a) SDG indicators. https://unstats.un.org/sdgs/report/2020/goal-04/

United Nations. (n.d.-b) Youth - United Nations sustainable development.

https://www.un.org/sustainabledevelopment/youth/

United Nations Department of Economic and Social Affairs. (2020). World youth report 2020.

https://www.un.org/development/desa/youth/wp-content/uploads/sites/21/2020/07/2020-WorldYouth-Report-FULL-FINAL.pdf

United Nations Security Council. (2015, December 9). Security council, unanimously adopting resolution 2250 (2015), urges member states to increase representation of youth in decision-making at all levels [Press release]. https://www.un.org/press/en/2015/sc12149.doc.htm

USAID. (2012). USAID youth in development policy. https://www.usaid.gov/sites/default/files/documents/1870/Youth in Development Policy 0.pdf

USAID. (2016). Positive Youth Development measurement toolkit. https://www.youthpower.org/sites/default/files/YouthPower/resources/PYD\%20Measurement\%2 0Toolkit\%20Final.pdf

USAID, Office of Democracy and Governance. (2002). Approaches to civic education: Lessons learned. https://pdf.usaid.gov/pdf docs/PNACP331.pdf 